\title{
Voicing the professional doctorate and the researching professional's identity: Theorizing the EdD's uniqueness
}

\author{
Pamela Burnard*, Tatjana Dragovic, Karen Ottewell \\ University of Cambridge, UK \\ Wai Mun Lim \\ Plymouth University, UK
}

\begin{abstract}
Although there is increasing interest in how learning to become a researching professional is understood by students undertaking a professional doctorate of education (EdD), the topic remains under-researched and under-theorized. In this article, we provide a set of theorizations, starting with the purpose and distinctiveness of the professional doctorate and the researching professional identity as this is understood by students and staff participating in the EdD programme in one university in the United Kingdom (UK). This is followed by a retheorization of the researching professional as they develop a reflexive disposition to connect the workplace and the university as the subject and object of the same critical stance. We explore: how the professional doctorate may be understood as practices of diverse researching professionals at different phases and stages of their doctoral journey; the imperative of critical reflexivity as one moves from practitioner to researching professional; and the placing of 'practice' at the nexus of the workplace, the university (doctoral programme) and leading professional change. We conclude with a merging of theorizations building on the being and doing of reflexive practice by EdD doctoral educators/supervisors and doctoral students/ researching professionals. Our theorizations are drawn from insights arising from recent EdD research projects (Burnard et al., 2016; Burnard et al., 2018; Heaton et al., forthcoming), and highlighted by narratives from two EdD students currently on a part-time EdD programme.
\end{abstract}

Keywords: theorizing doctorate journeying; researching professional; professional doctorate; leading professional change; reflexivity

\section{Introduction}

Professional doctorates have emerged in a wide range of academic disciplines, with the doctorate of education (EdD) having the largest market and imprint in the UK. The drivers for the development of professional doctorates are: the internationalization of higher education; the globalized knowledge market; the new knowledge economy; the impact of researching professional practice; and an increasing need for a critical approach by professionals and professional learning communities to their knowledge base and functions. As part of this changing picture, professional doctorates have grown rapidly in the UK, Australia and the USA. Within the professional doctorate, the concepts of knowledge creation, transfer and workplace professional capital create opportunities for shared research and innovation. This has become

\footnotetext{
* Corresponding author - email: pab6I@cam.ac.uk

(C) Copyright 2018 Burnard, Dragovic, Ottewell and Lim. This is an Open Access article distributed under the terms of the Creative Commons Attribution Licence, which permits unrestricted use, distribution and reproduction in any medium, provided the original author and source are credited.
} 
increasingly important in the relationship between higher education (HE), knowledge creation within academia, and the work and practice of professionals (Usher, 2002).

How researchers view and position themselves, as well as the identity of the researching professional in the workplace, can change. Whether situated as an insider or in-betweener, encountering new ideas, and embracing a willingness to accept one's identity as being fluid through engagement in a professional doctorate programme involves risk-taking; the outcomes of ongoing reflexive self-interrogation may be uncomfortable, personally, professionally, culturally and methodologically. The impact may be difficult to predict or control. This article draws on ideas, experiences, voices, journeyings and practices co-created by a community of doctoral educators and students who contribute to the development of transformative doctoral research practices on an EdD programme for professionals. Opening one's self to new ways of thinking and ways of being is profoundly challenging and unsettling, as our contributors' stories show.

In this article, we argue that the professional doctorate in education should recognize, advance and create new meanings, not only for leading professional change and commitment to improvement of practice but also for scholarship - where opportunities to learn for those participating in the study are an integral part, rather than a by-product, of the process.

The various dimensions of the professional doctoral programme, and the researcher's background, role and status in terms of professional and personal attributes, position the researching professional uniquely in relation to those that are researched and who take part in the study. How the boundaries between these various professional and personal attributes are fixed and interact with each other vary (Sultana, 2007).

The confluence of the interrelated factors that are the defining features of the professional doctorate (as shown in Figure I) indicates how policy is the background upon which the practice, theory and knowledge(s) operate. Policy often tends to be one-directional: that is, rarely are government policies, for instance, influenced by practice, theory and knowledge(s). Policy operates upon those circles of theory/practice/knowledge, often in ways that facilitate and shape them (at best), or limit and constrain them, or (at worst) undermine them. From the narratives of researching professionals and studies of professional doctorates, we can see how effective use of research and scholarship play a significant role in shaping the direction of the field and profession over time. Similarly, practice and theory can inform the direction and advancement of the profession and the field (Streitwieser and Ogden, 2016).

With the insistence and strong global focus on the knowledge economy, and discourses in the university, the workplace and the professions, there is a growing emphasis on the external drivers for the growth of professional doctorates. Knowledge creation in and across professional learning, and the training and continuous development of practitioners in communities, has also given rise to a changing conception of knowledge. Moreover, becoming part of a community of researching professionals from a variety of disciplines creates an epistemological challenge: a multi-professional space wherein what constitutes knowledge in a wide diversity of professional domains is represented.

In this article, we feature the views of two professionals, Karen Ottewell and Wai Mun Lim (both of whom have PhDs and are embarking on a second professional - work-based doctorate), who take a new view of professional action and advocate research into the kind of thinking that underlies and helps explain the way professionals carry out their work. They share professional knowledge that derives from professionals completing doctorates within their workplace, leveraging that understanding to reflect critically and reflexively on their daily practice with authority during the course of the doctorate. 


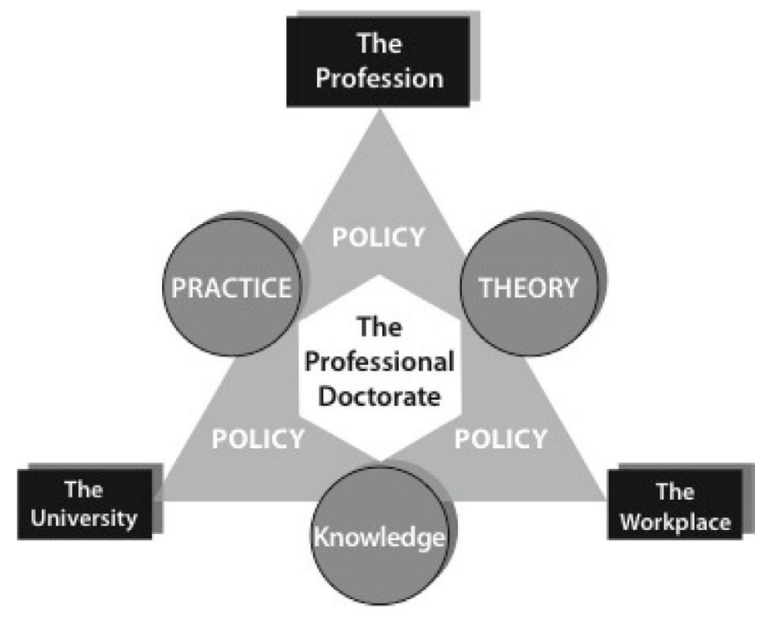

Figure I: The professional doctorate - its purpose and distinctiveness

\section{The researching professional}

As researching professionals critically revisit their 'practice', assumptions and values, generating an outsider's perspective on their own workplace, they develop identities that become multiple, flexible and changing. Why is that? We argue that, in the context of such change, and as their researcher positioning changes in the course of time, across and between multiple and discrete phases of research, they develop into critically reflexive researchers who are asking workbased and workplace questions. They are thus focused on changing and theorizing professional practices that are facilitated in the context of their own professional workplace.

As shown in Figure I, professionals are characterized by a codified knowledge base, and, as professionals, are expected to maintain familiarity with practitioner research guided by practice, or practice informed by research. Therefore, researching professionals doing EdDs engage in research that is not only guided by their professional knowledge and practice: the researching professional is part of that which is being researched. Saying the researcher is the research instrument has significant implications for the researcher's roles and responsibilities, positioning and reflexivity. Some researchers choose to engage as researching professionals who are increasingly co-constructing new relationships between theory and practice rather than through doctorates, which are seen as degrees that exist at the junction of practice and theory.

We argue that the practice of researching professionals extends beyond practitioner research, where the kinds of research conducted by practising teachers (and administrators) in a school setting show their dual role as practitioner and researcher, with the research focused and conducted on their own practice. The professional doctorate, however, focuses on issues raised by research that is interconnected with professional practice and professional knowledge within the insider-outsider continuum, involving relearning in the workplace, where the focus is on practice. From this perspective, some significant questions emerge around continuing changes in working conditions in professional practice at various career stages and phases (Burnard et al., 2016; Neumann, 2005). 


\section{Positioning changes and critical reflexivity}

In professional doctorate practices, the researcher is the instrument. The task of explicitly putting reflexivity to work and identifying oneself is therefore important. In order to clarify researcher identity and stance vis-à-vis participants, we must, as Gray (2008: 936) notes, 'address questions of the researcher's biographical relationship to the topic'. In professional doctorate research, researching professionals need to challenge their self-understanding, practising critical reflexivity so as to engage the researching professional's understanding of subjectivity, intersubjectivity, voice, representation and text, where reflexivity implies a deeper examination of underlying assumptions than the merely reflective. Reflexivity is bidirectional, where the act of self-reflection bends back on, refers to, and affects the entity - here meaning the researching professional - instigating the action or examination both critically and reflexively.

Within this context, being a researching professional occupies a privileged place - the insider - with both feet firmly balanced between the cultural systems and organizational learning specific to their workplace. There is no such clear boundary between outsider and insider for the professional researcher undertaking their own research in the professional setting.

According to Taylor (2007: 156), learning to become a researching professional involves balancing 'on the cusp' between the university, the work context and the profession. This highlights a number of questions concerning the roles and relationship of the university, the professional context and professional bodies. In a study of how learning to become a researching professional at doctoral level is understood by students, Taylor (2007: 164) emphasizes that the process 'is a complex intellectual and critical educational undertaking with unresolved tensions'.

Learning to become a researching professional places the learner at the intersection of their own professional practice, the organizational learning context in which they find themselves, their own professional development, and professional change process. Within this context, how researching professionals view themselves in the research process and context, as well as the identity of the researching professional, will shift, depending on the situation and the status of the researcher as an insider or outsider responding to the social, political and cultural values of a given context or moment. The insiderness and outsiderness can be seen as a balancing act between the positioning that the researching professional actively takes and the ways in which their role is defined by how others involved in the project, either as participants or those further afield, view the researcher. Shifting such positioning and building relationships of trust underlines the complexities of professional learning and development of an in-betweener researcher stance that challenges traditional dichotomies of the insider and outsider, and serves to highlight some pertinent issues about the nature of being and becoming a researching professional.

\section{The art and craft of professional doctorates and the researching professional identity}

Beijaard et al. (2004) emphasize that professional identity implies both person (the professional) and context (the professional practice), both of which are changing and co-influencing each other. And to make the whole process even more multilayered, during the course of professional doctorates the person element in this account is going through its own co-influential transformation from the practitioner (the insider identity) through the researcher (the outsider identity) to the researching professional (the in-betweener).

The intertwining identities of the researching professional are thus being co-created by the identity of practitioners who do it and the identity of researchers/scholars who study it, as shown in Figure 2. 


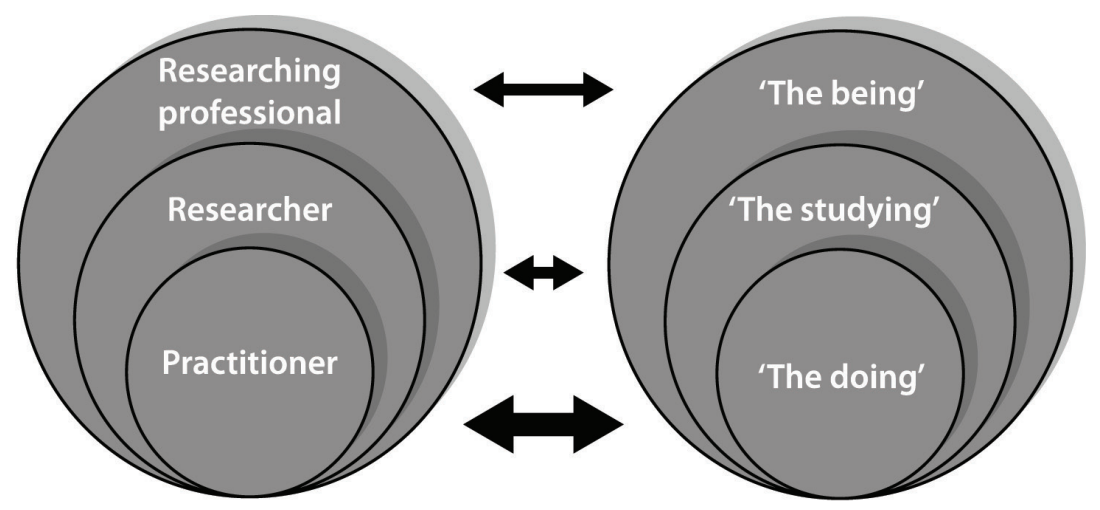

Figure 2: Overarching identity of the researching professional

This new professional identity is bigger than the sum of the two parts that it encompasses and, as Strauss (1962) argues, it can become a model of personal change or development. In Strauss's discussion of transformations of identity and self, one meets with new concepts and new classifications, and old ones are modified. Transformations involve 'radical change of action and person' since they 'connote shifts in perceiving, remembering and valuing' (Strauss, 1962: 66). Wenger (1998) builds on Strauss's idea of professional identity being a model of personal change and development by arguing that even though professional identity is being forged within the context of the profession, it transcends its boundaries, saying that 'the experience of identity in practice is a way of being in the world' (Wenger, 1998: 15I). Professional doctorate students thus do not only make a shift from the doing practitioner to the studying researcher (who examines and analyses), but change and develop through creating artistically a new professional identity that not only encompasses the previous two, but transcends them into, as Wenger suggests, 'the being in the world' (ibid.).

Professional doctorate students start their journeys as accomplished and experienced practitioners, and need to acquire skills to negotiate all the trials and navigate through their doctoral journeys. The creative and skilful process of moving from being a knowledgeable practitioner to the place of not knowing can be both exciting and painful. In spite of the skills professional doctorate students may either possess or acquire, managing the shift from the identity of a knowledgeable practitioner to a researching professional, which would encompass both the doing part of a practitioner and the studying part of a researcher, is a demanding task.

The art and craft of being a researching professional are brought to the fore by the combination of the following factors, existing on a continuum that the researching professional may move along:

I) the high-quality research and intense organizational knowledge and skills that help researching professionals to navigate the professional doctoral journey through meticulous balancing of the professional's practice and focus, and researcher's practice and focus in the work setting, on the one hand; and, on the other hand

2) the high-quality and intense creative process that doctoral students experience when facing artistic elements of the doctoral journey and identity transformations, that is those aspects that cannot be planned but do leave an unforgettable transformative trace 
3) the high-quality professional learning and pluralism in ways of understanding learning that allows one to know, act, and be a researching professional who performs diverse creativities, innovations and enterprise while developing new knowledge that contributes to the development of the professions (Burnard et al., 20l6).

Both the art and craft of professional doctorates were identified in a recent study of our professional doctorate students, where craft, creativities, competencies and critical reflexivity were identified as being central not only to carrying out their research, but also to navigating and negotiating changing practices in the workplace and changing pathways along their research journeys. This is where art and craft are needed, both on the side of the professional doctorate student, who is challenged to use reflexivity and critical awareness of his or her own situation, and on the side of doctoral educators and supervisors, who need to facilitate the student's resilience with carefully chosen supportive and coaching strategies (Heaton et al., forthcoming).

The next section offers accounts of two EdD students' first-hand experience (with intertwined doing, studying and being identities) of the art and craft of their professional doctorate journeys.

\section{Researching professionals storying their experiences of the EdD}

In Figure I, we saw that the professional doctorate is the confluence of interrelated factors, where policy is the background upon which practice, theory and knowledge operate. It is, moreover, this confluence of practice and theory that can inform the direction of the profession and the field (Streitwieser and Ogden, 2016). For the majority of those in the field of education who have decided to embark upon an EdD, practice and theory are largely separate entities in their respective professional realities: as teachers, their workplace is the educational institution where they exhibit their practice, on which they then theorize as practitioner-researchers through the framework of doctoral study at a university. The narratives that follow, however, are different in two important respects, in that not only have we already experienced the process of 'doctoring' (Tennant, 2004), to the extent that we are already 'doctored', but we are also senior academics working in UK higher education. (Dr Wai Mun Lim has a PhD in the management of internet technologies and is now an (associate professor) senior lecturer in service management at the University of Plymouth's Faculty of Business. Dr Karen Ottewell holds a PhD in eighteenth-century German literary history and is now the Director of Academic Development and Training for International Students at the University of Cambridge.) We therefore do not straddle the experiential divide that Taylor (2007: 157) highlighted: that of being, on the one hand, more expert than our supervisors in some aspects of professional knowledge, yet, on the other hand, novices in research and higher-level study. In our particular cases, the three points of this triangle intersect, since as university lecturers our workplace is the university, which is both the community of practice that we are looking to investigate through the professional doctorate and the body accrediting the EdD. While all who choose to become researching professionals have to contend with the dual nature of their new roles (Hajer, 1995), which lends them the perspective of 'insider-outsiderness' (Drake and Heath, $20 \mathrm{II}$ ), as academics whose workplace is the university, we are not only looking into the fishbowl from the outside as an insider, we are already insiders of that very framework through which researching professionals gain their perspective of outsiderness, namely the university. Our experiences therefore require a reworking of this triangle to reflect the complex nature of our roles as researching-professionals, since we already 'inhabit ... the hyphens' (Drake and Heath, $20 \mathrm{II}: 25)$, albeit in the inverse relationship of professional practitioners and researchers. 


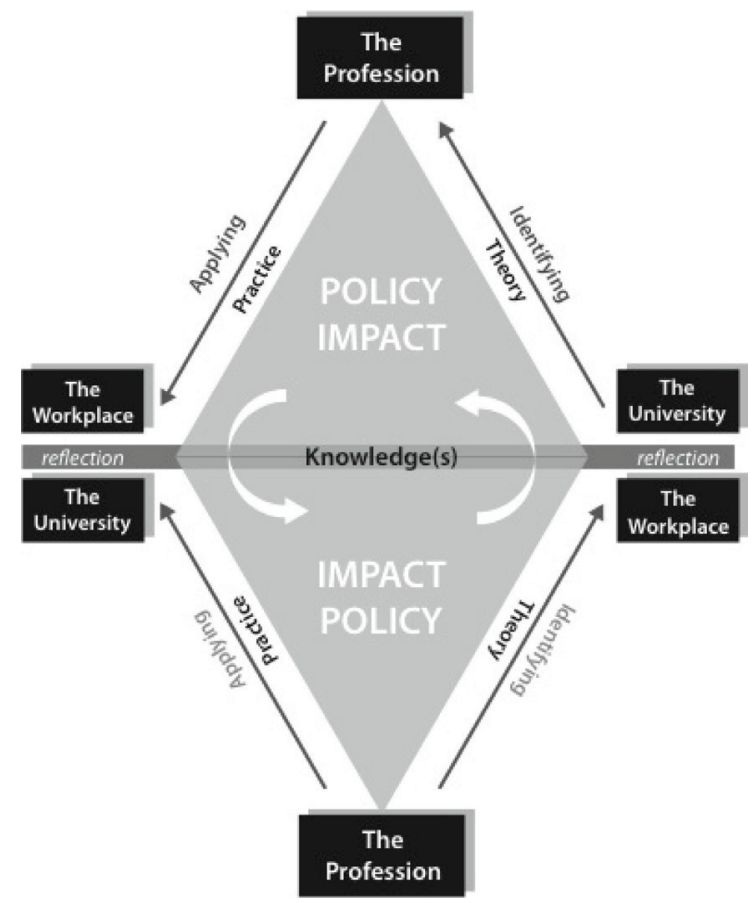

Figure 3: A reflective representation on the being and doing of a professional doctorate and researching professionals' reflexive practice being-in-relation

Figure 3 attempts to capture our reworking of the model of the professional doctorate as a confluence of interrelated factors, and the fact that our experiential reality of this process is markedly different to those who embark on this journey from the pre-HE teaching profession. For them, the relationship between the workplace and the university, between practice and theory, is arguably more unidirectional: the university provides the theoretical framework through which they can analyse and act as a catalyst of change in their own and their community's practice. While we do also operate on this plane, for us the relationship between the different spheres is less defined and arguably more bidirectional. We are still using the university's theoretical framework to examine and analyse our own practices, but these are set within that very framework that shapes our theoretical approach. As university lecturers who teach and research, we are now not only scrutinizing our own teaching practices as an insider looking in from the outside with a view to (hopefully) effecting impact and policy change within our respective spheres, we are also standing outside our own research practices, looking in on these from the outside as an insider through a different epistemological lens.

\section{Researching professionals in practice: Two narratives}

In the following narratives, we will attempt to provide a critically reflective account, storying our experiences of the EdD, by looking back to our motivations for starting on this journey, through to where we are now, in the middle of our second year of a five-year part-time EdD, before looking forward to where we are hoping to be and who we are hoping to become at the end of this reflexive doctoral process. 


\section{Narrative I: Dr Wai Mun Lim}

While the motivation for my first doctorate was purely achievement based, the impetus for the second was my experience of managing a new undergraduate degree programme. As a reflective practitioner, I was drawn to the pedagogic enquiry as to where and how my students have progressed in the final year of my undergraduate degree programme. While getting myself acquainted with the broad range of qualifications considered for admission, I learnt of the competing ideas about higher education institutions with a foreign presence. The more I read, the more questions I had. I realized that I needed to frame the context of knowledge gathering (learning), and so I decided to formalize the process by embarking on a major research journey that would not only satisfy a personal curiosity but also address enquiries and concerns in my professional practice.

Looking at the narrative of my journey in the first two terms of the EdD programme, I progressed from developing a general overview of the issues that I wanted to examine in my workplace, to identifying theories that could address these questions. At the start of this process, I was able to position myself as an insider (of the university) but with an outsider perspective (the profession), which led to the development of the proposal. As we moved through the academic terms, I found myself repositioning from an insider to an outsider who was gazing inwards. This shift in positioning occurred as I struggled to encapsulate the numerous pathways a student could follow to obtain a degree. This struggle was further complicated because my knowledge of the degree pathways was limited to what was being delivered or approved at the university at which I work.

Recognizing this shift in my epistemological enquiry, I began examining the stakeholders of degree pathways. This quickly led to the identification of many variations of collaborations between a university and other education providers.

Adopting the role of an outsider looking inwards as an insider enabled me to refine the subject of my research enquiry to alternative higher education providers. While I appeared to have successfully contextualized the parameters of my study, it soon became clear that the theoretical underpinnings guiding my research question had to be further developed and strengthened. During this phase, I drew upon my three key roles as an academic in a post1992 university: (I) as a programme manager (and personal tutor) of a one-year, Level-6, direct-entry degree programme; (2) as a lecturer and module leader who writes and delivers curriculum to direct-entry students; and (3) as a researcher. Prior to the EdD, my research was primarily conducted to inform the curriculum I teach; however, as I have journeyed on the EdD programme, it has triggered two layers of professional reflexivity analogous to that suggested by Schön (1987). The first is reflection on action, where I reflect on past situations in relation to my degree programme, and consider if my actions were appropriate and how they would affect future practice. The second is reflection in action, where I am recurrently learning and advancing from current and past experiences and rationalizing, as situations occur.

The culmination of these roles compels me to read across disciplines, and it is no coincidence that I am wearing my service-management-researcher hat to augment the pedagogic approaches in refining my research framework. As we approach the end of the second year of the EdD, the obligatory submission of the registration viva document is looming. In this programme, the registration viva occurs in the fifth term of the EdD. It follows training in research methods culminating in the preparation of a 20,000-word portfolio-type document. This document involves an intense building of assemblages, or collection of chapters, tracing the gaps and absences in the relevant literatures, the rationale for the research focus, and a defining of challenges, concepts and debates, with a setting out of the proposal, methods, research processes, researcher positioning, research design, data collection and analysis for producing/ 
collecting empirical material that will further our understanding and insights into professional practice. As I write this reflective narrative, I am weaving together the key theories that I will be adopting to address my research questions and, critically, to develop my research design. As my proposed research problems require an examination of 'real-life contextual understandings, multi-level perspectives, and cultural influences' (Weine, 2015: 450) from an epistemological perspective, the first phase of data collection will take on a social constructivist approach.

As we have intimated in our co-authored chapter (Ottewell and Lim, 2016), the EdD and the $\mathrm{PhD}$ are akin to running a marathon. While the mileage and mandatory effort to train is no different for a successful completion, the 'training' in the EdD differs in that the identification of theory, and the applicability to practice, has an immediate influence on my profession in the workplace. I have long been aware of the broader management implications of my practice as a programme leader and lecturer, but, as a researching professional looking inwards, I became reflexively aware of how applying theory to practice could have an effect on individual students. In my PhD, 'training' did not involve any immediate consequence that I could act upon in practice. As I was an outsider peering into a business sector, any impact would only have been detected after the publication of the findings of the study.

Moving forward, the university not only provides conceptual and methodological tools but also framing of joint activity concerned with the professional setting of my workplace reality, in which my professional self and professional practice reside. I have learned not to take for granted the ways in which we narrativise our identities, and how we come to be where and who we are for the professional self (of the authors) in the professional workplace. I have come to know what contribution researching as a professional, and what researching those practices, makes, in addition to the professional knowledge(s) created in professional settings in which leadership-enabling learning and engagement with evidence emerges (Gronn, 2002).

\section{Narrative 2: Dr Karen Ottewell}

My primary motivation to do a second, professional doctorate was simply that this would provide me with a framework of critical reflexivity through which I would be able to research my own and my community's professional practice, with a view to being better at my job. My professional role is to support (primarily) international students whose first language is not English in developing the necessary discipline-specific academic literacies required at (primarily) postgraduate level (although increasingly this support is being widened to include first-language English speakers). As Bourdieu noted, 'academic language is no-one's mother tongue' (Bourdieu and Passeron, 1994: 8), and this is nowhere more apparent than in the domain of writing. In my EdD research, I am therefore looking to both design and implement a framework to provide transitional support for the development of written articulacy at postgraduate level by looking behind the writing to investigate, and thereby hopefully better understand, this cognitively demanding and highly complex process - since at postgraduate level, in particular, it is so much more than merely writing; it is the creation of knowledge. By undergoing this doctoral process again, I will also be better placed to understand the process that the students I support are undergoing themselves.

Initially, my greatest challenge was dealing with the refraction of roles that doing the professional doctorate both in and at my own institution engenders. As I reflected in our coauthored chapter:

I am a University Senior Lecturer and a Graduate Student at the same time in the same institution, where my practitioner role is to support the development of written academic literacy - the very practices of which, however, I am both researching and in the process of (re-)developing myself. I 
am therefore not only looking into the fishbowl from the outside as an insider, but in the role of researcher I need to practice those very skills that I am researching and which I, as a practitioner, teach (Ottewell and Lim, 2016: 35).

In fact, in the light of our reworking of the model of the professional doctorate above, my experience of this reflective insider-outsiderness, which is central to the professional doctorate, is actually refracted on to four separate and yet interdependent strata: (I) general: as a researching professional who is researching their own practice; (2) HE focus: as a researching professional whose professional environment is the academy; (3) university level: as a researching professional who is doing the EdD at the same institution where I am a practitioner; and (4) researcher level: as a researcher who must now also (re)develop those very practices that I, as a researching professional, am researching and that, as a professional practitioner, I teach. This refraction of roles and identities will undoubtedly provide a unique insight, but it is a multifaceted, subjectiveobjective relationship of which I will need to be constantly consciously aware throughout the entire EdD.

Yet as I come to the end of the second year of my EdD, with my registration report driving the coalescence of my thoughts and ideas into a spatially and temporally defined research project, the nature of my challenge has shifted. The refraction of my identities still forms the background to my experiential reality, but it is my past experiences of doctoral study together with the ultimate reason that I embarked on this particular journey that currently shape my experience. By this, I mean that I have become more consciously aware of my repositioning, not simply in my new role as a researching professional researching my own practices, but also in the different perspective of the research process that this affords me through the framework of the EdD as opposed to that of the PhD. In my PhD, while I was, of course, still aware of the general direction of travel of my research, the research process was one, I felt, of gradually uncovering new connections that I could then weave into a coherent whole. My direction of travel was horizontal - I was progressing the knowledge of my field further either by pushing past boundaries or by redefining them, thereby forging new insights in the process. It was as if I was journeying through a tunnel, shedding new light step by step, until I reached its end where, looking back on the accumulation of details I had uncovered along the research journey, I was then in a position to draw the conclusions that I had merely been able to surmise before I stepped into it.

In the EdD, on the other hand, I feel as if my relationship to that which I am researching is far more vertically defined. The concept of insider-outsiderness is, of course, still pertinent, but as a professional with over two decades of professional experience and expertise in the field I am now researching, I am far more knowledgeable about this field than the 21 -year-old me was of the field I was researching back then. As a consequence, my perspective seems to be very much one of being above what I am researching. I know the field, since it is the one in which I have been a practitioner for more than two decades - a practitioner in both senses: of having taught the practices of writing and also of having practised those practices of writing as a writer. My approach to both has been research-informed, in that I have always sought out ways to better support the students I have taught, and so I am aware of the main theories and approaches to unpacking the cognitively demanding task of writing. Yet my role has been receptive - one of being research-informed. My role is now active, in that the incompleteness I have witnessed in my field - where it has not been able to answer the questions that I as a practitioner have posed - have led me to become the researcher and to look from the outside inside. However, instead of the horizontal perception of my research as traversing along a tunnel as I was with the PhD, I feel as if I am above my field and community of practice, very much as the outsider looking in, but as one who is aware of the terrain but is seeking a better path through it. I know what it 
is that I am looking for; I just need to construct the best methodological framework in order, hopefully, to find it.

This experience aligns quite readily with the different starting points for the two modes of doctoral research: a PhD tends to start with a question; while an EdD tends to start with a problem. A PhD is also seen as a stepping stone on an academic career path, just as the EdD may be a stepping stone in their professional development for those in primary and secondary education. As already 'doctored', however, my interest lies less in the award of academic titles, or in the character-building experience that all doctoral study undoubtedly is, but far more in finding a solution to the problem I have posed. Unlike the PhD, where the spatial and temporal framework of a PhD at Cambridge (say, 60,000-80,000 words within three years) was a welcome guiding structural framework (and cutting my research cloth, so to speak, to fit this framework was seen as part of the training to become a researcher), in the EdD I find myself less concerned with the framework. While still a necessary structural guideline, and indeed still a requirement for the award of the EdD, I find that my focus is far more that the cut of my research cloth is driven by my desire to find the best solution I can to the problem that has brought me on this journey. This has resulted in an ambitious research design, one that could perhaps be split into two or more doctoral research projects. I can only hope at this stage that my previous experience of 'doctoring', together with my two decades of professional experience, will ensure a successful outcome. For me, however, the success of this outcome will be gauged far more by whether I have had an impact on practice and have effected a practical change than by the award of the Level 8 qualification. While I may be on my way to becoming and being a researching professional, my motivation is anchored in my role as practitioner.

While my PhD may have made an 'original and well-researched ... valuable contribution to eighteenth-century scholarship' (Baughan, 2004: 828), with the EdD I want to make a significant impact in my professional setting: first, by advancing the understanding and teaching of written academic literacy of my community of practice and second, thereby enhancing the efficiency and effectiveness of my professional role, making connections between the university and the workplace. By researching practice through a different epistemological lens, that is as a researching professional, I wish, as an active agent, to advance the theory relativism of my discipline so as to develop and refine professional practice further in ways in which research and practice coexist.

\section{Professional repositioning, theorizing EdD practice and leading professional change}

This article is based on the premise that all education is a reflective and reflexive process by its very nature, as it seeks to expand the horizons both of those being educated and those doing the educating. This is also true of all doctoral journeying and the arduous process of making 'a significant contribution to learning', as required, for example, by one of the criteria that the University of Cambridge defines for the award of a PhD (University of Cambridge, 20I8). It is a demanding journey, physically and emotionally, as well as intellectually. While the $\mathrm{PhD}$ student must reflect on their own research practices and harness their inner drive so as to advance the boundaries of knowledge in their discipline, their stance in this process is that of the outsider looking in. Not so with EdD researching professionals. The distinctive nature of professional doctorate programmes at many universities is different: researchers are insiders trying to look inside and make sense of their own professional workplace as a researching professional through the eyes of an outsider. Their insiderness offers a unique vantage point, one that arguably is not 
accessible through the lens of the $\mathrm{PhD}$. But this vantage point comes at a cost, personal (as in the demanding journey of the $\mathrm{PhD}$ ), but also professional, in that they must attempt to objectify and theorize that which they subjectively practice. This repositioning of the professional identity at the nexus of practice and theory takes them closer to achieving Aristotle's phronesis (that is, wisdom in determining ends and the means of attaining them), but this journey is far more arduous, not least because they are not only personally but also professionally invested in the outcome.

In summary, we have looked at the identity of the researching professional and the complexities of researching professionals' roles from the point of view of students undertaking a professional doctorate of education in our university. Our two EdD students, in their storying, argued that in spite of having already been 'doctored', their EdD journeys opened new spaces and opportunities for creating the complex and active identity of a researching professional. The complexity of the researching professional identity is multifaceted, and particularly overwhelming when practitioners look into the fishbowl not only from the outside as an insider, but also as insiders of the university through which researching professionals usually develop the perspective of outsiderness. In addition to this intertwined repositioning of different roles, the key features and key potentials of professional doctorates lie in the immediacy of their significant impacts in professional settings. These impacts are made possible due to the reflexive and active agency of the researching professional's identity, which is skilfully and artistically crafted as being through the merging of the doing of the practitioner and the studying of the researcher. The following section discusses how the immediacy of impact and the complexity of the researching professional identity can be used to refocus the debate about professional doctorate education on to leading professional change.

\section{Theorizing EdD practices: Leading professional change}

In this section, we introduce a different way of thinking about the work of doctoral education and doctoral research for professionals and their professional learning communities. We invite those who are working in and with EdDs, along with those who are forming identities as researching professionals with a focus on professional practice or those deciding to embark on a professional doctorate, to rethink how we understand the multifaceted practice of professional doctorates in education as being at the forefront of leading professional change.

When we invite researching professionals (our EdDs) to reflect on and write about why their profession and professional practice really needs researching - why this topic, why now, why them, why here (supported by a particular university) and why there (in that workplace)? - they generate many questions about identifying and applying theory, and understanding how policy contexts mediate professional practice. In professions with extensive evidenceand practice-based guidelines for decision-making, such as education, medicine and industry, professional options to change in accordance with these guidelines are now rarely simply 'delivered'. As argued by Hofmann (2016: 143), leading professional change, 'including how and why professional guidelines are (not) implemented - cannot be fully and systematically understood or explored without research'. In addition to understanding barriers to professional change, we need to understand how these barriers - including policy, practice and theory interact with the professional workplace setting. The gap between practice, research and theory has commonly been explained through a deficit model, relating to the lack of knowledge of professionals and practitioners. Generating new knowledge(s) using theory or developing new theories from practice can interact with the professional setting and its learning culture, as well as the potential pathways to, and mechanisms of, change (Flutter, 2016). These interactions 
and interconnections are featured in Figure 4, our final theorization, which is concerned with the uniqueness of the professional doctorate in relation to the researching professional and the knowledge(s) created by breaking down binaries of professional/academic, pure/applied, theory/practice, policy/non-policy, and reconstituting them as something new, emancipatory and transformative. While it is acknowledged that for some institutions, "neither professional doctorates (EdDs) nor "traditional" PhD programmes are homogeneous' (Bourner et al., 200I: 69) and that they are, in practice, interchangeable, others maintain that the two routes are essentially different. In the latter view, the professional doctorate (EdD) is identified as an alternative to the $\mathrm{PhD}$, the $\mathrm{PhD}$ offering a route for those wanting to become professional researchers rather than researching professionals.

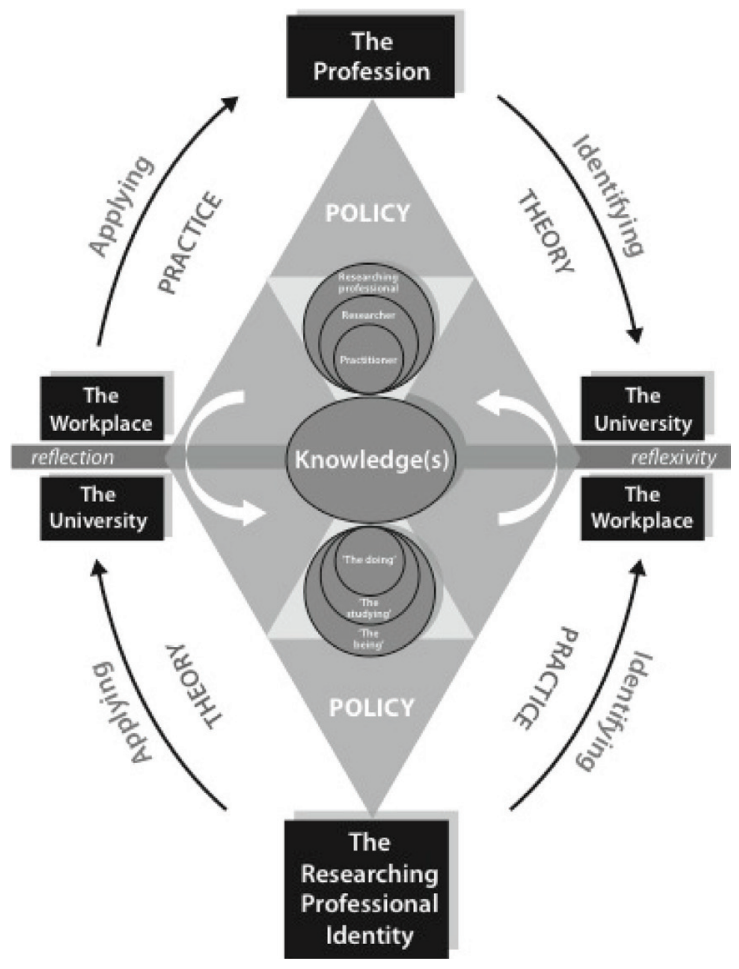

Figure 4: Theorizing the uniqueness of the professional doctorate

\section{Closing reflections}

From the moment we became involved in the professional doctorate programme, it has been an inspirational, life-changing experience. We feel like professional fellow travellers and voyagers; we each see the transformative potential of professional doctorate programmes that provide us with the capacity to act as crucibles for creating knowledge together and raising questions in doing, studying and being researching professionals together.

The issues that arise from the distinctiveness of professional doctorates are concerned with how views are shared, how university lecturers are inducted into the EdD teaching teams, and the interface between the professional work-based learning community and the university. Further developments in ways of thinking about what it means to be a researching 
professional - an EdD student and educator - can result in new perspectives, voices, journeyings and practices, genuinely leading to professional change through purposefully educative research by professionals.

\section{Notes on the contributors}

Pamela Burnard is Professor of Arts, Creativities and Education at the Faculty of Education, University of Cambridge (www.educ.cam.ac.uk/people/staff/burnard/). She co-convenes the British Educational Research Association (BERA) Special Interest Group, Creativities in Education (www.bera.ac.uk/group/creativities-in-education), and the biennial international conference, 'Building interdisciplinary bridges across cultures and creativities' (www.BIBACC. org). She is EdD programme manager, lecturer and supervisor. She is an international authority on creativities research across diverse learning contexts.

Tatjana Dragovic is a doctoral educator and a leader of the Leadership, Educational Improvement and Development (LEID) research community at the Faculty of Education, University of Cambridge. For the last 23 years she has worked across different disciplines, sectors and industries, and is recognized as an international educator, whose interdisciplinary expertise and research interests lie in the fields of creativity, leadership development, coaching, and the professional and personal development of educators.

Karen Ottewell is Director of Academic Development and Training for International Students section at the University of Cambridge, which provides training to assist international students in further developing and honing the skills required to succeed in an English-speaking academic context. She is currently in the second year of her EdD on the design and implementation of a framework to provide transitional support for the development of written articulacy at PG level.

Wai Mun Lim is a senior lecturer in the Faculty of Business at Plymouth University and has many years of experience in managing undergraduate and postgraduate research degree programmes. She is currently pursuing an EdD, and her research interests include the value of higher education, the internationalization of higher education and alternative higher education providers.

\section{References}

Baughan, J. (2004) 'Lessing and the "Sturm und Drang": A reappraisal revisited'. Modern Language Review, 99 (3), 827-8.

Beijaard, D., Meijer, P.C. and Verloop, N. (2004) 'Reconsidering research on teachers' professional identity'. Teacher and Teaching Education, 20 (2), I07-28.

Bourdieu, P. and Passeron, J.-C. (1994) 'Introduction: Language and relationship to language in the teaching situation'. In Bourdieu, P., Passeron, J.-C. and de Saint Martin, M. Academic Discourse: Linguistic misunderstanding and professorial power. Trans. Teese, R. Cambridge: Polity Press, I-34.

Bourner, T., Bowden, R. and Laing, S. (200I) 'Professional doctorates in England'. Studies in Higher Education, 26 (I), 65-83.

Burnard, P., Dragovic, T., Flutter, J. and Alderton, J. (eds) (2016) Transformative Doctoral Research Practices for Professionals. Rotterdam: Sense Publishers.

Burnard, P., Holliday, C., Jasilek, S. and Nikolova, A. (2018) 'Artists and arts-based method use in higher education: A living inquiry of an academic programme in a faculty of education'. In Chemi, T. and Du, X. (eds) Arts-Based Methods and Organizational Learning: Higher education around the world. London: Palgrave Macmillan, 29I-325.

Drake, P. and Heath, L. (20II) Practitioner Research at Doctoral Level: Developing coherent research methodologies. London: Routledge. 
Flutter, J. (2016) 'Connecting the voices, journeyings and practices of the doctorate for professionals'. In Burnard, P., Dragovic, T., Flutter, J. and Alderton, J. (eds) Transformative Doctoral Research Practices for Professionals. Rotterdam: Sense Publishers, |57-6I.

Gray, B. (2008) 'Putting emotion and reflexivity to work in researching migration'. Sociology, 42 (5), 935-52. Gronn, P. (2002) 'Distributed leadership as a unit of analysis'. Leadership Quarterly, 13 (4), 423-5I.

Hajer, M.A. (1995) The Politics of Environmental Discourse: Ecological modernization and the policy process. Oxford: Clarendon Press.

Heaton, R., Burnard, P., Nikolova, A., Igglesden, T., Williams, D., Joomun, R., Peacock, F., Rogers, B. and Wong, S. (forthcoming) '(Re-)conceptualising doctoral education as a living autographic site for professionals'. International Journal of Education in the Arts.

Hofmann, R. (2016) 'Leading professional change through research(ing): Conceptual tools for professional practice and research'. In Burnard, P., Dragovic, T., Flutter, J. and Alderton, J. (eds) Transformative Doctoral Research Practices for Professionals. Rotterdam: Sense Publishers, I4I-54.

Neumann, R. (2005) 'Doctoral differences: Professional doctorates and PhDs compared'. Journal of Higher Education Policy and Management, 27 (2), 173-88.

Ottewell, K. and Lim, W.M. (2016) 'PhD: Been there, done that: So, why do a (second), professional doctorate?'. In Burnard, P., Dragovic, T., Flutter, J. and Alderton, J. (eds) Transformative Doctoral Research Practices for Professionals. Rotterdam: Sense Publishers, 29-4I.

Schön, D.A. (1987) Educating the Reflective Practitioner: Toward a new design for teaching and learning in the professions. San Francisco, CA: Jossey-Bass.

Strauss, A. (1962) 'Transformations of identity'. In Rose, A.M. (ed.) Human Behaviour and Social Processes: An interactionist approach. London: Routledge and Kegan Paul, 63-85.

Streitwieser, B. and Ogden, A.C. (eds) (2016) International Higher Education's Scholar-Practitioners: Bridging research and practice. Oxford: Symposium Books.

Sultana, F. (2007) 'Reflexivity, positionality and participatory ethics: Negotiating fieldwork dilemmas in international research'. ACME: An International e-Journal for Critical Geographies, 6 (3), 374-85.

Taylor, A. (2007) 'Learning to become researching professionals: The case of the doctorate of education'. International Journal of Teaching and Learning in Higher Education, 19 (2), I54-66.

Tennant, M. (2004) 'Doctoring the knowledge worker'. Studies in Continuing Education, 26 (3), 43I-4I.

University of Cambridge (2018) 'Cambridge students: PhD, MSc, MLitt and MPhil by dissertation'. Online. www.cambridgestudents.cam.ac.uk/your-course/examinations/graduate-exam-information/writingsubmitting-and-examination/phd-msc-mlitt (accessed 4 January 2018).

Usher, R. (2002) 'A diversity of doctorates: Fitness for the knowledge economy?'. Higher Education Research and Development, 2I (2), I43-53.

Weine, S. (2015) 'Applying multimethod and mixed methods to prevention research in global health'. In Hesse-Biber, S. and Johnson, R.B. (eds) The Oxford Handbook of Multimethod and Mixed Methods Research Inquiry. Oxford: Oxford University Press, 447-65.

Wenger, E. (1998) Communities of Practice: Learning, meaning, and identity. Cambridge: Cambridge University Press.
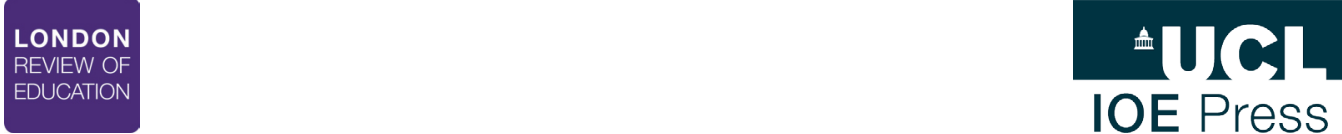
IOE Press

This paper is part of a London Review of Education special feature: 'The EdD at 20: Lessons learned from professional doctorates', edited by Denise Hawkes, Sridevi Yerrabati and Susan Taylor. 


\section{The other articles in the 'EdD at 20' feature are:}

Bamberger, A. (2018) 'Academic degree recognition in a global era: The case of the doctorate of education (EdD) in Israel'. London Review of Education, 16 (I), 28-39.

Chua, S.M.J. (2018) 'Being written: Thinking the normative in the EdD'. London Review of Education, I6 (I), 56-62.

Cunningham, B. (2018) 'Pensive professionalism: The role of "required reflection" on a professional doctorate'. London Review of Education, 16 (I), 63-74.

Hawkes, D. and Yerrabati, S. (2018) 'A systematic review of research on professional doctorates'. London Review of Education, 16 (I), 10-27.

Hawkes, D., Yerrabati, S. and Taylor, S. (2018) Editorial: 'The EdD at 20: Lessons learned from professional doctorates'. London Review of Education, 16 (I), I-3.

Lunt, I. (2018) Introduction to 'The EdD at 20: Lessons learned from professional doctorates'. London Review of Education, 16 (I), 4-9.

Moran, E. and Misra, D. (2018) 'Professional doctorates: A pathway to legitimacy for non-academic HE professionals?' London Review of Education, I6 (I), 75-89.

Robinson, C. (2018) 'The landscape of professional doctorate provision in English higher education institutions: Inconsistencies, tensions and unsustainability'. London Review of Education, I6 (I), 90-I03.

Taylor, S. (2018) 'The UCL EdD: An apprenticeship for the future educational professional?' London Review of Education, 16 (I), 104-2I. 